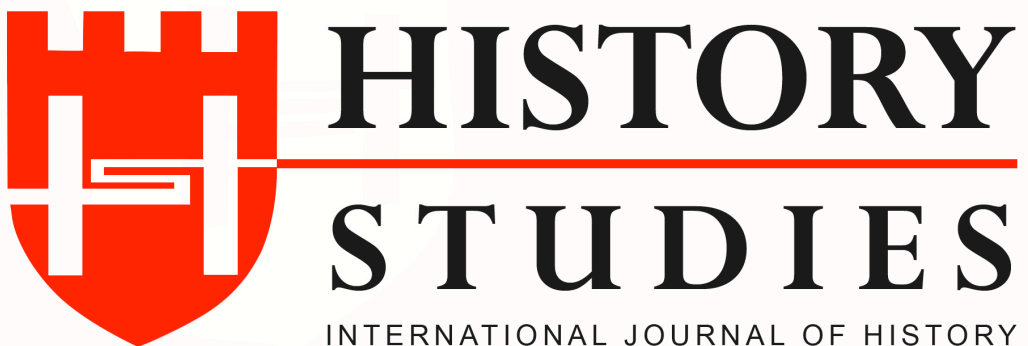

ISSN: 13094173 (Online) 1309 - 4688 (Print)

Volume 11 Issue 2, A Tribute to Prof. Dr. Mehmet Ali ÜNAL, April 2019

DOI Number10.9737/hist.2019.732

Araştırma Makalesi

Makale Geliş Tarihi: 10.01.2019 - Kabul Tarihi: 09.02.2019

Atıf Künyesi: İsmail Efe, “NATO’ya Üyelik Sürecinde Türkiye-ABD İlişkileri ve Türk Kamuoyundaki Akisleri”, History Studies, 11/2, Nisan 2019, s. 601-619

\title{
NATO’ya Üyelik Sürecinde Türkiye-ABD İlişkileri ve Türk Kamuoyundaki Akisleri
}

Relations Between Turkey And The USA in The Process of Membership to NATO and The Currents in Turkish Public Opinion

\author{
Dr. İsmail EFE \\ ORCID No: 0000-0002-8958-6604 \\ Kirlkkale Üniversitesi
}

Öz: Bütün dünyada büyük ylkımlara sebep olan İkinci Dünya Savaşl, savaşta yer alan ülkelerde ekonomik krizlere sebep olurken, Avrupa ve dünya güç dengelerinin değișmesini de tetikledi. İkinci Dünya Savaşı'ndan güçlenerek ve nüfuzunu artırarak çıkan, sadece Amerika Birleşik Devletleri ve Sovyet Rusya oldu. Savaștan güçlenerek çıkan Rusya, yayılmacı bir siyaset izlemeye başladı. Sovyet Rusya'nın, Türkiye'den toprak ve boğazlarda üs talebinde bulunmaya başlaması, idarecileri endişeye sevk etti. Bu tehditlere tek başına karşı koyamayacağını düşünen Türkiye, batılı devletlerle özelliklede ABD nezdinde ittifak araylşlarına giristi. ABD'nin, Avrupa ülkelerini ekonomik yönden güçlendirme projesi olan Marshall yardımlarından kısmen faydalanan Türkiye, bütün çabalarına rağmen, 4 Nisan 1949'da Washington'da imzalan, Kuzey Atlantik Antlaşması'nda yer alamadı. NATO'ya girme mücadelesini ısrarla sürdüren Türkiye, Birleşmiş Milletlerin Kore Savaşı'na asker gönderilmesi çağrısını bir firsat olarak gördüğünden olumlu cevap verdi. Türkiye'nin Kore'ye asker göndermesi, ABD'nin Türkiye bakışının değişmesine sebep oldu. ABD'nin, 15 Mayıs 1951'de Türkiye'nin NATO'ya kabul edilmesi yönündeki teklifi, 20 Eylül 1951'de NATO Bakanlar Konseyi toplantısında kabul edildi. TBMM'nin 18 Şubat 1952'de onayı ile Türkiye NATO'ya girdi. Sovyet Rusya tehdidini hisseden Türk kamuoyu ve basını da yaşanan süreci hassasiyetle takip etti.

Anahtar Kelimeler: İkinci Dünya Savașı, Sovyet Rusya, Türkiye-ABD, NATO, Türk Kamuoyu.

Abstract: The Second World War, which caused great destruction all over the world, caused economic crises in the countries involved in the war, while the balance of power between Europe and the world triggered the change. It was only the United States and Soviet Russia that emerged from the Second World War, strengthening and increasing its influence. Russia, which grew stronger from the war, began to pursue expansionist politics. Soviet Russia began demanding bases in the Straits and lands of Turkey, prompting the rulers to worry. Considering that Turkey cannot resist these threats alone, it has started to seek alliance with Western states in particular with the United States. Turkey, which partly benefited from the Marshall Aid, which was a project to strengthen European countries economically, was not included in the North Atlantic Treaty, which was signed in Washington on April 4, 1949. Persistently continuing the struggle of joining NATO, Turkey, the United Nations sent troops to the Korean War as a chance to his call for us to be seeing this, gave a positive answer. Turkey's sending troops to Korea has changed the U.S.'s view of Turkey. On May 15, 1951, the U.S. proposal for Turkey's admission to NATO was accepted at the NATO Council of Ministers Meeting on September 20, 1951. With the approval of the Grand National Assembly on 18 February 1952, Turkey entered NATO. The Turkish public and the press, who felt the threat of Soviet Russia, followed the process with precision.

Keywords: The Second World War, Soviet Russia, Turkey-USA, NATO, Turkish Public Opinion. 


\section{Giriş}

Dünya'nın yeni bir savaşa doğru hızla sürüklendiği günlerde, Türkiye kendi toprak bütünlüğünü muhafaza etme ve olası bir savaşın dışında kalma siyaseti takip ediyordu. Bu sırada Almanya ve İtalya'nın yayılmacı politikalar izlemesi, Türkiye'nin anti revizyonist düzenin devamını isteyen- devletlerle yakınlaşmasına sebep oldu. Bölgesinde özellikle İtalya'nın faaliyetlerinden rahatsızlık duyan Türkiye, İngiltere ile anlaşarak 12 Mayıs 1939 tarihinde barışın korunmasını ihtiva eden bir beyanname yayınladı. Türkiye bu beyanname ile barışın devamına taraf olan blokta yer aldığını dünya kamuoyuna deklare etmiş oldu. ${ }^{1}$ Beyannamede Türkiye ve İngiltere'nin kendi güvenliklerini ihtiva eden bir ittifak imzalayacakları, buna ilaveten Akdeniz havzasında ve Balkanlarda güvenliğin tesisinin gerekliliği ifade edilmişti.

İngiltere ve Fransa ile yapmayı planladığı ittifaka Sovyet Rusya'yı da dâhil etmek isteyen Türkiye, görüşmelerde bulunmak üzere Dişişleri Bakanı Saraçoğlu'nu 25 Eylül 1939'da Moskova'ya gönderdi. Görüşmeler sırasında Sovyetlerin, Türk Boğazlarının savunulmasında yer alma, Montrö Boğazlar Sözleşmesi'nde değişiklik yapılması yönündeki talepleri görüşmelerin sonuçsuz kalmasına sebep oldu. ${ }^{2}$ Yapmayı tasavvur ettiği ittifaka Rusya'yı da dahil etme girișiminden sonuç alamayan Türkiye, 19 Ekim 1939'da İngiltere ve Fransa ile karşılıklı yardım antlaşması imzaladı. ${ }^{3}$ Türkiye daha savaş başlamadan yaptığ 1 ittifaklarla savaşın dışında kalma, güvenliğini ve bütünlügünü muhafaza etme siyasetini savaş yıllarında da devam ettirdi. Yaklaşık altı yıl devam eden İkinci Dünya Savaşı boyunca, savaşta yer alan tarafların Türkiye'yi savaşa sokmak için gösterdikleri yoğun çabalara, hatta zaman zaman baskı ve toprak vaatlerine rağmen savaşın dışında kalmayı başardı. ${ }^{4}$

Savaşın sonlarına doğru Almanya'nın askeri gücünün zayıfladığını, savaşı kaybedeceğini gören Türkiye, İngiltere ve ABD'den de barış konferansında müttefik olarak değerlendirileceğine dair teminat alınca 2 Ağustos 1944'te Almanya ile diplomatik ilişkilerini kesti. ${ }^{5}$ Türkiye arkasından da üzerindeki Sovyet Rusya baskısını hafifletmek ve batılı devletler ile yakınlaşmak amacıyla göstermelikte olsa, 23 Şubat 1945 'te Almanya ve Japonya'ya savaş ilan etti. Savaş ilanıyla Türkiye BM'ye katılım hakkı kazanmış oldu. ${ }^{6}$

İnsanlık tarihinde görülen en büyük felaketlerden biri olan İkinci Dünya Savaşı, 1945 yılı Mayıs'ında Avrupa'da, Eylül ayında ise Asya'da sona erdi. Savaşın sona ermesiyle Asya ve Avrupa kıtalarında güçler dengesinde büyük boşluklar meydana geldi. Çünkü İkinci Dünya Savaşı'nda gerek galip gelen İngiltere, Fransa gibi gerekse de yenilen Almanya, İtalya ve Japonya gibi ülkeler savaştan büyük ölçüde yıpranmış ve zarar görmüş olarak çıktılar. Savaş sonunda güçlü olarak ayakta kalabilenler ise, Avrupa'ya göre iki "kenar" devlet, olarak nitelenen ABD ve Sovyet Rusya oldu. Amerika Birleşik Devletleri, savaş sonunda yeniden kıtasına çekilme eğilimi içindeyken, Sovyet Rusya ise yayılma düşüncesine sahipti. ${ }^{7}$

\section{1. İkinci Dünya Savașı Sonrası Gelișmeler}

\footnotetext{
${ }^{1}$ Ali Kemal Meram, Türk-Rus İlişkileri Tarihi, Kitaş Yayınları, İstanbul 1969, s.291.

${ }^{2}$ Durmuş Yalçın vd., Türkiye Cumhuriyeti Tarihi II, Atatürk Araştırma Merkezi Yay., Ankara 2002, s. 450-451.

${ }^{3}$ Feridun Cemal Erkin, Dışişlerinde 34 Yıl, Anılar-Yorumlar, C. I, TTK Yayınları, Ankara 1987, s.136.

${ }^{4}$ Wayne Bowen, “Türkiye ve İkinci Dünya Savaşı: Taraflı Fakat Savaşmayan Ülke”, (Çev. Mehmet Emin Baysal), Türkler Ansiklopedisi, C. XVI, Yeni Türkiye Yayınları, Ankara 2002, s.811.

${ }^{5}$ Selim Deringil, Denge Oyunu; İkinci Dünya Savaşı'nda Türkiye'nin Dış Politikası, Tarih Vakfı Yurt Yayınları, İstanbul 2003, s.244; A. Şükrü Esmer-Oral Sander, vd., Olaylarla Türk Dış Politikası, Alkım Yayınevi, Ankara 1989, s.183.

${ }^{6}$ Cumhuriyet, 24 Şubat 1945, s. 1; "San Francisco'ya Dün Resmen Davet Edildik” Cumhuriyet, 7 Mart 1945, s.1.

${ }^{7}$ Fahir Armaoğlu, 20. Yüzyıl Siyasi Tarihi (1914-1980), C. I, İş Banaksı Yay. Ankara 1991, s.402; Uçarol, age, s.616-660.
}

\section{History Studies}


İkinci Dünya Savaşı'nın başından sonuna kadar çarpışan İngilizler, savaşın kazananları arasında yer aldı. Ancak, İngilizler savaşı sürdürebilmek için hem ülke ekonomisini hem de İngiliz halkını büyük ölçüde zorladılar ve rezervlerini tükettiler. ${ }^{8} 1940-1945$ yılları arasında Avrupa'da 450 bin kilometrekarelik bir alanı ve 24 milyon nüfusu sınırları içine katan Rusya, hiç kuşkusuz savaştan en karlı çıkan ülkelerden biriydi. ${ }^{9}$ Özellikle savaşın son yıllarında, müttefikler arasında görüş farklılıklarından kaynaklanan anlaşmazlıkların ortaya çıkması, savaşın sona erdiği tarihlerde, dünya devletlerinin iki ayrı kutba ayrılmasına neden oldu. Bu durum Birinci Dünya Savaşı'ndan sonra kurulan dünya güçler dengesinin yıkılmasına yol açt1. ${ }^{10}$

Sovyet Rusya, İkinci Dünya Savaşı sonunda müttefiki olan diğer devletlerin kamuoylarındaki ve ekonomilerindeki olumsuz havadan faydalanıp mevcut durumu kendi çıkarları doğrultusunda kullanarak Avrupa'da istediği gibi hareket etmeye başladı. ${ }^{11}$ Rusya, bir taraftan savaş sırasında işgal ettiği Doğu ve Orta Avrupa ülkelerini peykleştirirken, diğer yandan da kendisi için stratejik öneme haiz olan Türkiye, Yunanistan ve İran üzerinde bask1 yapmaya başladı. Türkiye üzerinde emellerini daha 1945 yılında Yalta ve Potsdam konferansları sırasında belli eden Rusya, Boğazlarda üs, Kars ve Ardahan'ın da kendisine terk edilmesini istedi. ${ }^{12}$ Potsdam Konferansı'nda İngiltere ve ABD, Sovyetler Birliği'nin, Boğazlar konusundaki taleplerine itiraz etmesiyle Sovyet Rusya hedefine ulaşamadı. ${ }^{13}$

Savaştan sonra Rusya'nın Türkiye'den toprak talebi ve Boğazlardan üs isteği Türk kamuoyunda ve basında büyük tepkilere sebep oldu. Rusya'ya taleplerine karşı en sert tepkilerden birini de Cumhurbaşkanı İsmet İnönü gösterdi. İnönü, topraklarımızdan ve sahip olduğumuz haklardan hiç kimseye taviz verilmeyeceğini, topraklarımız ve haklarımız uğruna gerekirse şerefimizle mücadele ederek ölüneceğini ifade etti. ${ }^{14}$ Dönemin bütün gazetelerinde Rus taleplerine karşı tepkileri içeren çok sert haber ve yorumlar yer aldı. Basında yer alan tepkilerden birisi de dönemin önemli gazetecilerinden birisi olan Hüseyin Cahit Yalçın'a aitti. Hüseyin Cahit Yalçın Tanin Gazetesi'ndeki yazısında, Sovyet Rusya'nın Türkiye'den toprak talebinde bulunarak gerçek yüzünü ortaya koyduğunu söyledi. ${ }^{15}$

Akdeniz ve Ortadoğu bölgesinde büyük çıkarları bulunan İngiltere, içinde bulunduğu şartlarda Rusya'ya karşı çıkarlarını koruyamayacağının farkındaydı. Adı geçen bölgelerdeki çıkarlarını Rusya'ya kaptırmak istemeyen İngiltere, kendi yerini alabilecek ve aynı zamanda Sovyet Rusya'nın bu bölgede yayılmasını durdurabilecek bir devlet arayışına girdi. Bu devlette Amerika Birleşik Devletlerinden başkası değildi. Ancak, Amerika da savaş sonunda kendi kamuoyunun etkisiyle, yeniden kıtasına çekilme politikasına dönme eğilimindeydi. İngiltere karşı karşıya bulunulan Rus tehdidinin vahametini Amerika Birleşik Devletleri'ne 21 Şubat 1947 'de iki nota ile bildirdi. İngiltere, verdiği notada içinde bulunduğu ekonomik bunalım nedeniyle Türkiye ve Yunanistan'da bulunan askerlerini geri çekmek zorunda olduğunu, bu iki ülkenin askeri ve ekonomik yönden desteklenerek bölgede dengenin bir nebze olsun

\footnotetext{
${ }^{8}$ Paul, Kennedy, Büyük Güçlerin Yükselişi ve Çöküsleri, (16.Yüzyıldan Günümüze Ekonomik Değişim ve Askeri Çatışmalar), (Çev. Birtane Karanakçı), İş Bankası Yay., İstanbul 2002., s.437-438.

${ }^{9}$ Türkkaya Ataöv, Amerika-Nato ve Türkiye, Aydınlı Yayınevi, Ankara 1969, s.64.

${ }^{10}$ Rifat Uçarol, Siyasi Tarih (1789-1999), Filiz Kitabevi, İstanbul 2000, s.618.

${ }^{11}$ Sadık Atak, Harp Sonrasinda Dünya, (1945-1966), Ankara Basım ve Ciltevi, Ankara 1966, s.1.

${ }^{12}$ Gothard Jaeschke, “I. ve II. Dünya Savaşları'nda Türkiye'nin Dış Politikası”, Türkler, C.XVI, Yeni Türkiye Yay. Ankara 2002, s.801.

${ }^{13}$ Mehmet Gönlübol, A. Haluk Ülman, Olaylarla Türk Dış Politikası, (1945-1965 Dönemi), Siyasal Kitabevi

Yayınları, Ankara 1996, s.185; Yalçın vd., age, s.460.

14"“Milli Şefin Tarihi Nutku”, Cumhuriyet, 2 Kasim 1945, s. 1.

${ }^{15}$ Hüseyin C. Yalçın, "Üçüncü Dünya Harbi Tehlikesi Karşısında Türkiye”, Tanin, 27 Haziran 1945, s.1.
} 
sağlanabileceğini, bu sorumluluğun Amerika Birleşik Devletleri'ne düştüğünü ifade etti. ${ }^{16}$ İngiltere, Amerika Birleşik Devletleri'nin Yunanistan ve Türkiye'ye yardım etmemesi durumunda iki ülkenin Sovyet Rusya'nın peykleri arasına gireceğini, bunun da müttefikler adına çok büyük kayıp olduğunu belirtti. İngiltere'nin notası üzerine harekete geçen ABD Dışişleri Bakanı Marshall, yaptığı çalışmalar sonunda hazırladığ 1 raporları Başkan Truman'a sundu. ${ }^{17}$

Birinci Dünya Savaşı sonrasında olduğu gibi İkinci Dünya Savaşı sonrasında da kıtasına çekilmek düşüncesinde olan Amerika Birleşik Devletleri, İngiltere'nin girişimi ile bu düşüncesinden vazgeçerek, dış politikasında köklü bir değişikliğe gitti. ABD, 2 Aralık 1823'de "Vandenberg Kararı" adıyla bilinen Monroe Doktrinini açıkladığı tarihten itibaren dışişlerinde yalnızlık politikası olarak bilinen siyasetine, Truman Doktrini ve Marshall Planını uygulamaya koyarak son verdi. Dış politikasında yaptığı değişiklikle ABD, diğer devletlerle ittifaklar yapma, kıtasının dışındaki devletlerle işbirliğine girişme sürecini başlattı. ${ }^{18}$

Savaştan sonra hızlı bir şekilde sınırlarını genişleten Sovyet Rusya, 1945-1948 yılları arasında bir milyon kilometrekare toprak ile 92 milyon nüfusu kontrolü altına almış, muazzam bir coğrafyaya hakim olmuş durumdaydı. ${ }^{19} \mathrm{Bu}$ tarihlerde Türkiye, yayılmacı bir siyaset izleyen Sovyet Rusya karşısında kendisini güvende hissetmiyor, toprak bütünlüğünü ve bağımsızlığını korumaya çabalıyordu. Türkiye, karşı karşıya bulunduğu Sovyet tehdidine ancak Batı dünyası ile bütünleşerek karşı koyabileceğini düşünüyordu. Bu anlayış doğrultusunda batılı devletler ve özellikle de ABD ile yakınlaşmaya çalışıyordu. ${ }^{20}$

\section{Sovyet Rusya'nın Yayılmacı Siyaseti ve ABD (Truman Doktrini ve Marshall Planı)}

İkinci Dünya Savaşı'ndan sonra yayılmacı bir siyaset izleyen Sovyet Rusya, Türkiye'nin de içinde yer aldığı batılı devletler için ciddi bir tehdit haline geldi. Bu tehdit karşısında kendisini güvende hissetmeyen batılı ülkeler, ABD nezdinde yardım arayışına girdiler. Amerika Birleşik Devletleri, batılı ülkelerin Sovyet tehdidine karşı koyabilmeleri için desteklenip güçlendirilmelerinin gereğine inanıyordu. Başkan Truman, 12 Mart 1947'de Kongre'ye sunduğu beyannamede, Sovyet Rusya'nın tehdidi altında bulunan ülkelere ekonomik ve askeri yardım yapılması gerektiğini söyledi. Başkanın talebi üzerine hazırlanan yardım programı "Truman Doktrini" adıyla uygulamaya konuldu. Sovyetler Birliği'nin yayılmasını durdurabilmek için, Avrupa devletlerinin ekonomik yönden güçlendirilmesi gerekiyordu. Bir plan dahilinde Avrupa devletlerine yardım yapılmasına karar verildi. Avrupa ülkelerini Rusya karşısında güçlü kılabilmek için Amerika Birleşik Devletleri Dışişleri Bakanı George Marshall'ın adıyla anılan Marshall Yardımı uygulamaya geçirildi.

\subsection{Truman Doktrini}

Avrupalı ülkeler, hayat tarzlarını ve toprak bütünlüklerini Sovyet tehdidine karşı koruya bilmek için Amerika Birleşik Devletleri'ni garantör olarak görmeye başladılar. ${ }^{21}$ Rusya'nın özellikle Avrupa ve Ortadoğu'da hızlanan yayılmacılık politikasına karşı Amerika'nın ilk ciddi

\footnotetext{
${ }^{16}$ A. Haluk Ülman, Türk-Amerikan Diplomatik Münasebetleri, 1939-1947, Sevinç Matbaası, Ankara 1961, s.93-94; Atak, age, s.1.

${ }^{17}$ Melih Esenbel, Türkiye'nin Batı ile İttifaka Yönelişi, İsis Yayımcılık, İstanbul 2000, s.53.

${ }^{18}$ Uçarol, age, s.670.

${ }^{19}$ Ataöv, age, s.64.

${ }^{20}$ Oral Sander, Türkiye’nin Dış Politikası, İmge Kitabevi Yayınları, İstanbul 2006, s.155-156; Hikmet Öksüz, “Türkiye Cumhuriyeti Devleti'nin Balkan Politikası”, Türk Dış Politikası - Cumhuriyet Dönemi, C. II, Gökkubbe Yayınları, İstanbul 2008, s.17.

${ }^{21}$ Ali, Arsın, "Soğuk Savaş'ın Kaynakları ve NATO’nun Kuruluşuna Yol Açan Gelişmeler”, NATO Savunma ve Eğitim Yönleri Sempozyumu, Ankara Üniversitesi Eğitim Bilimleri Fakültesi Yayınları, No:133, Ankara 1984, s.6-7.
} 
girişimi, Truman Doktrini oldu. ${ }^{22}$ Amerika Birleşik Devletleri'nin bu girişimi, dış politikasında köklü bir değişiklik yaptığını, dünya güçler dengesini oluşturmak üzere harekete geçtiğinin işaretiydi. Truman Doktrini, dünyanın iki bloğa ayrıldığını, Sovyet-Amerikan mücadelesinin başladığını açıkça ilan etmekle kalmıyor, "Soğuk Savaş" olarak nitelenen dönemin de ilk adımlarını atıyordu. Bu dönemde ABD'nin uluslararası politikasının temel esasını Sovyet karşıtllı̆ı oluşturuyordu. ${ }^{23}$

Rus yayılmacılı̆̆ı karşısında Batı Blok'unun liderliğini üstlenen Amerika Birleşik Devletleri yetkilileri, bu bloğu oluşturacak ülkelerin bir an önce İkinci Dünya Savaşı'nın kötü etkilerinden kurtularak daha da güçlenmelerinin gerektiğine inanıyordu. ABD yetkilileri bu ülkelerin güçlenmesinin tek yolunun maddi yardımlar yapılması ve teçhizat yönünden desteklenmesi ile mümkün olduğunu düşünüyorlardı. Uygulamaya konulması düşünülen yardım politikası, Sovyet tehdidiyle karşı karşıya bulunan Türkiye'yi de kapsıyordu. Çünkü Türkiye, savaş yıllarında olduğu gibi Soğuk Savaş'ın başlangıcı olarak kabul edilen 1946 yılından itibaren yoğun Rus baskılarına ve isteklerine karşı koyabilmek amacıyla, ordusunu savaş durumunda tutmak zorunda kalmıştı. ${ }^{24}$ Savaş sona ermiş olmasına rağmen Türkiye, ordusunu terhis etmemiş, ekonomik durumunu geliştirmek için önemli kararlar alamamıştı. ABD’nin 1947 yılında Truman Doktrinini deklere etmesinde Sovyetler Birliği’nin Türk Boğazlarında askeri üs talebi ve Türkiye'ye karşı açık Sovyet saldırı ihtimali etkili oldu. ${ }^{25}$

Amerika Birleşik Devletleri Başkanı Truman, 12 Mart 1947'de Kongre'ye sunduğu beyannamede, Sovyet Rusya'nın tehdidi altında bulunan ülkelere ekonomik ve askeri yardım yapılması gerektiğini söyledi. Bu anlayış doğrultusunda hazırlanan program dünya tarihinde "Truman Doktrini” olarak yer aldı. ${ }^{26}$ Doktrin özgür ve demokratik ülkelerin "silahlı azınlıklar ve dış baskılara karşı" korunmalarını ve Sovyetler Birliği'nin çevrelenmesini amaçlıyordu. Truman, kongre üyelerine yaptığ 1 konuşmada, tehdit altında bulunan ülkeleri korumak için Türkiye ve Yunanistan'a 400 milyon dolarlık- yardım yapılmasını talep etti. Bununla birlikte her iki ülkenin isteği doğrultusunda sivil ve askeri personelinin yardım programı çerçevesinde eğitilmesi hususunda da yetki istedi. ${ }^{27}$

Truman'nın talebi 22 Nisan'da Senato'da, 9 Mayıs'ta Temsilciler Meclisi'nde "Yunanistan ve Türkiye'ye Yardım Kanunu" tasarısı olarak kabul edildi. Tasarı 22 Mayıs 1947'de de Başkan Truman tarafından onaylanarak yürürlüğe girdi. Böylece Amerika Birleşik Devletleri, Yunanistan'a 300 milyon, Türkiye'ye de 100 milyon dolarlık yardımın yapılmasını kabul etmiş oldu. Truman Doktrini çerçevesinde Türkiye'ye yapılan yardımlar, daha çok yol yapımı ve bakımı, kargo ulaşımının geliştirilmesi, silahlı kuvvetlerin eğitimi ve silahlandırılması ile hava alanlarının onarılmasında kullanıldı. ${ }^{28}$ Türk idarecileri, Truman Doktrini çerçevesinde Amerika Birleşik Devletleri tarafından Türkiye'ye verilen askeri ve ekonomik yardımı, Sovyet tehdidine

\footnotetext{
${ }^{22}$ Oral Sander, Türk-Amerikan İlişkileri 1947-1964, Ankara Üniversitesi Siyasal Bilgiler Fakültesi Yayınları, Ankara 1979, s.11-12; Gündüz, Uluksar, "İkinci Dünya Savaşı Öncesi ve Savaşın Devamında Türk-Rus İlişkileri”, Altıncı Askeri Tarih Semineri Bildirileri II, Genelkurmay Basımevi, Ankara 1999, s.404.

${ }^{23}$ Oral Sander, Balkan Gelişmeleri ve Türkiye (1945-1965), Sevinç Matbaası, Ankara 1969, s.57.

${ }^{24} Y$ Yusuf Sarınay, Türkiye'nin Bati Itttifakı'na Yönelişi ve NATO’ya Girişi (1939-1952), Kültür ve Turizm Bakanlığ Yayınları, Ankara 1988, s.49.

${ }^{25}$ Hasret Çomak, “İkinci Dünya Harbi ve Türkiye, Harbin Sonrasında Türkiye-ABD İlişkileri, ABD’nin Türkiye'ye Yardım Politikası (Truman Doktrini ve Marshall Planı)”, Altıncı Askeri Tarih Semineri Bildirileri I, Genelkurmay Basımevi, Ankara 1998, s.467.

${ }^{26}$ Allan Nevins-Henry Steele Commager, Amerika Birleşik Devletleri Tarihi, (Çeviren H. İnalcık), Varlık Yayınevi, İstanbul 1961, s.453.

${ }^{27}$ Gönlübol-Ülman, age, s.213-214.

${ }^{28}$ A. Haluk Ülman, Türk-Amerikan Diplomatik Münasebetleri, 1939-1947, Sevinç Matbaası, Ankara 1961, s.96; Sander (1969), age, s.24.
} 
karşı bir güvence ve caydırıcı unsur olarak görüyordu. Ayrıca, İkinci Dünya Savaşı'ndan en güçlü devlet olarak çıkan ABD'den yardım alınması, Türk dış politikasının bir başarısı olarak değerlendiriliyordu. ${ }^{29}$

\subsection{Marshall Planı}

Sovyetler Birliği’nin yayılmasını durdurabilmek için, Avrupa devletlerinin muhakkak ekonomik yönden kalkınması ve güçlendirilmesi gerekiyordu. Bunun için bir plan dahilinde Avrupa devletlerine yardım edilmeliydi. Fakat bu sadece Amerikan yardımıyla değil aynı zamanda Avrupa'nın da istemesiyle ve çabasıyla olabilirdi. Truman Doktrini ile başlayan süreci, Amerika Birleşik Devletleri Dışişleri Bakanı George Marshall'ın adıyla tarih sayfalarında yer bulacak olan Marshall Yardımı takip etti. Yapılacak yardımlar istikrarın, ekonomik entegrasyonun ve nihayetinde güçlü müttefiklerin oluşmasını sağlayacaktı. Zor durumda bulunan ülkelere gereken yardımların yapılması Amerika'nın hayati çıkarları için de önemliydi. Aksi takdirde Amerikan ekonomisi bu durumdan zarar görecekti. ${ }^{30}$

12 Temmuz 1947 'de Paris'te İngiltere ve Fransa'nın öncülügünde aralarında Türkiye'nin de bulunduğu 16 Avrupa ülkesi bir konferansta Marshall Planı'nı ele aldı. 22 Eylül'de de Amerika’ya sunulmak üzere "Avrupa Ekonomik Kalkınma Raporu” hazırlandı. 16 Aralık 1947 tarihinde ise Marshall Planı'nın uygulanması için düzenlenen Amerikan kanun projesi, Başkan Truman tarafından Kongre'ye gönderildi. 4 sene için 17 milyarlık bir yardımı kapsayan bu plana 'Avrupa'nın Kalkınma Programı' adı verildi. ${ }^{31} 3$ Nisan 1948'de Amerika Birleşik Devletleri "Dış Yardım Kanunu” çıkardı. 16 Nisan 1948'de ise Marshall Planı'nı onaylayan 16 Avrupa devleti tarafından "Avrupa İktisadi İşbirliği Teşkilatı" kuruldu. Bu teşkilatın asıl görevi ekonomik işbirliği planlarını hazırlamak ve uygulamak, üye devletlerin çalışmalarını gözlemlemek, Amerikan Hükümetine yardım paralarının dağıtılması konusunda yardımcı olmaktı. $^{32}$

Marshall Yardımından Türkiye de yararlanmak istiyordu. Fakat Türkiye'nin Marshall Yardımından yaralanmasıyla ilgili, programda herhangi bir açıklama bulunmuyordu. Üstelik Türkiye, İsviçre ve Portekiz gibi ekonomi ve sanayi alanında kendisinden daha iyi ülkelerle aynı kategoride değerlendiriliyordu. Bu değerlendirmenin nedeni ise Türkiye'nin o sırada ödeme dengesinin açık vermemesi ve Merkez Bankası'nda kullanıma hazır bir miktar altın ve dövizinin bulunmasıydı. Türkiye'ye Amerika tarafından Marshall Yardımı yerine uzun vadeli finansman imkanların önerilmesi, Türkiye'de büyük bir hayal kırıklığı yarattı. Uzun vadeli finansman kaynağı temininin adresi olarak da uluslararası bir kredi kurumu olan Dünya Bankası gösterildi. ${ }^{33}$

Türkiye'yi ekonomik bakımdan yalnız bırakan ABD'nin, ileride politik bakımdan da yalnız bırakabileceği kuşkuları hissedilmeye başlandı. Bu gelişmeler üzerine Türk Hükümeti, doğrudan ABD Hükümeti'ne başvurarak, Türkiye'nin siyasi ve coğrafi bakımdan çok önemli bir konuma sahip olduğunu, bu konumunun mali ve ekonomik güçlükler yarattığını bildirdi. Ayrıca güçlü olmanın tek koşulunun ekonomik kalkınma olduğunu, bunun için de şimdilik tek yolun dış yardım olduğunu ve ABD’nin ekonomik yardım konusundaki görüşlerini yeniden

\footnotetext{
${ }^{29}$ Cemalettin Taşkıran, “Türkiye Niçin NATO’ya Girdi”, Askeri Tarih Bülteni, C.XXV, S. 49, Genelkurmay Basımevi, Ankara 2000, s.5; Sander (1969), age, s.22.

${ }^{30}$ Baskın Oran, Türk Dış Politikası,1919-1980, C.I, İletişim Yayınları, İstanbul 2002, s.538.

${ }^{31}$ İsmail Soysal, Türkiye'nin Uluslararası Siyasal Bağıtlart (1945-1990), C.II, TTK. Yay., Ankara 1991, s.50.

${ }^{32}$ Aptülahat Akşin, Türkiye'nin 1945'den Sonraki Dış Politika Gelişmeleri, Ortadoğu Meseleleri, İsmail Akgün Matbaacılık ve Kitapçı1ık Müesseseleri, İstanbul 1959, s.18.

${ }^{33}$ Esenbel, age, s.63.
} 
gözden geçirmesi gerektiğini ifade etti. ${ }^{34}$ Türkiye'nin Truman Doktrininden de fazla yararlanamadığını, yapılan yardımın yeterli olamayacağını ifade eden Türk Hükümeti, süratle Paris ve Washington'a Marshall Yardımından faydalanmak için girişimlerde bulunmak üzere birer heyet gönderdi. ${ }^{35}$ Türkiye'nin girişimleri sonucunda Truman Doktrini ile yapılan yardımın yeterli olmadığına ikna olan Amerikan Birleşik Devletleri Hükümeti, 4 Nisan 1948'de imzalanan ekonomik işbirliği antlaşmasıyla, Marshall yardımı kapsamına Türkiye'yi de dahil etti. $^{36}$

Türkiye, Marshall Yardımı programından ilk yıllarda çok az miktarda yararlanabildi. 1948-1951 yılları arasında Türkiye, toplam 351.700 .000 dolarlık bir yardım aldı. Aldığ1 Marshall yardımı ile ülke genelinde tarım ve sanayinin güçlü temeller üzerine oturması için uğraştı ve parasının istikrarını arttırmaya çabaladı. Ekonomik istikrara önem veren Türkiye, diğer Avrupa devletleri ile işbirliğini sıkılaştırma çabası içine girdi. ${ }^{37}$ Truman Doktrini ve Marshall Yardımı ile Türk dış politikasında yeni bir dönem başladı. Sovyetler Birliği'nin özellikle Doğu Anadolu ve Boğazlar üzerindeki yayılmacı ve genişlemeci emellerinin Doğu Akdeniz'de hayata geçmesi engellendi. Ayrıca Türk Ordusu'nun ve ekonomisinin savaş sonrasında yeniden yapılanmasına zemin hazırland. ${ }^{38}$

\section{NATO'nun Kuruluş Süreci ve Türkiye}

Sovyet yayılmacılı̆̆ kapsayacak bir güvenlik paktı kuma çabası içine girdi. Türk Hükümeti, ABD ve İngiltere'ye yapılmaya çalış1lan güvenlik paktında Türkiye'nin düşünülüp düşünülmediğini sordu. Türkiye'ye anlaşmasının Kuzey Atlantik bölgesi ülkeleri ile sınırlı olacağı söylendi. 4 Nisan 1949 tarihinde, toplam on iki ülkenin katılımıyla geniş kapsamlı bir savunma ittifakı olan "Kuzey Atlantik Antlaşması Örgütü (NATO: North Atlantic Treaty Organization)" kuruldu. Türk basınında, Türkiye'nin NATO dışında bırakılması şiddetle eleştirildi. Kurulduğunda üye olarak kabul edilmemesine rağmen Türkiye, üyelik mücadelesini 1srarla sürdürdü. Türkiye, Birleşmiş Milletlerin Kore'ye askeri birlikler gönderme çağrısına, 25 Temmuz 1950 tarihinde olumlu cevap veren ikinci ülke oldu. Türk kuvvetlerinin Kore muharebelerdeki üstün başarıları, Batı dünyasında Türkiye'ye karşı olumlu tepkilerin oluşmasını sağladı. Türkiye'nin NATO ittifakı açısından önemini kavrayan ABD, 15 Mayıs 1951'de Yunanistan ve Türkiye'nin NATO'ya alınması talebeni resmen üye ülkelere teklif etti. NATO Bakanlar Konseyi'nin, 1620 Eylül 1951 tarihleri arasında Ottawa'da yaptığı toplantının sonunda, özel bir oturumda Türkiye ve Yunanistan'ın NATO'ya üye olarak çağırılmalarına oybirliği ile karar verildi. 18 Şubat 1952 tarihinde Türkiye'nin NATO'ya girmesine ilişkin kanunun TBMM'de onaylanması ile üyelik kesinleşmiş oldu.

\subsection{NATO'nun Kuruluşu ve Türk Kamuoyundaki Yansımaları}

Sovyet Rusya'nın yayılma tehdidine karşı ilk ciddi işbirliği girişimi 17 Mart 1948'de İngiltere, Fransa, Belçika, Hollanda ve Lüksemburg arasında imzalanan "Brüksel Antlaşması" oldu. Bu anlaşma, üye ülkelerin mevcut kuvvetlerini birleştirmeyi amaçlıyordu. ${ }^{39}$ Antlaşmanın imzalandığı sırada Sovyet tehdidini en çok hisseden ülkeler Türkiye ve Yunanistan olmasına rağmen, bu iki devlet Brüksel Antlaşması'na dâhil edilmedi. ${ }^{40}$ Türkiye, üye olarak kabul

\footnotetext{
${ }^{34}$ Çomak, age, s.473.

${ }^{35}$ Sander (1969), age, s.53.

${ }^{36}$ Oran, age, s.541.

${ }^{37}$ Soysal, age, s.46; Gönlübol-Ülman, age, s.249.

${ }^{38}$ Çomak, age, s. 474 .

${ }^{39}$ Soysal, age, 75.

${ }^{40}$ Erkin, age, s.267.
} 
edilmemesine rağmen, Bürüksel Anlaşması'nın yapılmış olmasını olumlu karşıladı. Dönemin Türkiye Dışişleri Bakanı Sadak, yapılan bu anlaşmaların Rus tehdidi karşısında bulunan ülkelerin endişelerini azaltacak mahiyette olduğunu söyledi. ${ }^{41}$

ABD, Sovyetler Birliği'nin Avrupa'da yarattığı yayılma tehdidinin, Kuzey Atlantik ülkelerini de içine alacak şekilde genişleyebileceğinden endișe ediyordu. Bu düşünceden hareketle Amerikalı senatör Vandenberg, 11 Haziran 1948'de, ABD'nin, Avrupa'da bir ittifaka katılabilmesi için gereken yasal düzenlemeyi senato gündemine taşıyarak kabul edilmesini sağladı. Senatonun aldığı bu kararla, ABD'nin de içinde yer alacağ 1 bir ittifakın kurulması önünde hiçbir hukuki engel kalmadı. Bu sırada Türkiye 30 Haziran 1948'de ABD'ye ittifak teklif etti, ancak olumlu bir cevap alamadı. ABD'ye yaptığı ittifak teklifi reddedilen Türkiye, Batı Avrupa Birliği'ne girmek için ABD'nin arabuluculuk yapmasını istedi. Fakat Türkiye'nin bu isteği de ABD tarafından dikkate alınmadı. ${ }^{42}$

Sovyet yayılmacılığı tehdidine karşı Batı Avrupa ülkeleri ve ABD Atlantik bölgesini kapsayacak bir güvenlik paktı kuma çabası içine girdi. Batı da güvenlik paktı kurma arayışları sürerken, Türk Hükümeti, ABD ve İngiltere'ye yapılmaya çalışılan güvenlik paktında Türkiye'nin düşünülüp düşünülmediğini sordu. Türkiye'ye verilen cevap; düşünülen güvenlik anlaşmasının Kuzey Atlantik bölgesi ülkeleri ile sınırlı olacağı, yani Türkiye'nin dahil edilemeyeceği şeklinde oldu. Ancak, Türkiye'ye Akdeniz Bölgesi için yeni bir güvenlik paktı anlaşmasının yapılacağı söylendi. ABD ve İngiltere arasında Türkiye'nin pakta kabul edilmeyeceği hususunda kesin bir görüş olmasına rağmen 1srarını sürdüren Türkiye, 1949 başlarında anlaşmaya dahil edilmeyi tekrar talep etti. Hatta Türk Dışişleri Bakanı Necmettin Sadak, bu amaçla 1949 Şubatında destek arayışlarında bulunmak üzere Londra, Paris ve Brüksel'e bir ziyareti yaptı. Bütün çabalarına rağmen Türkiye güvenlik paktına giremedi ancak, 13 Mart 1949 tarihinde Amerika Birleşik Devletleri Dışişleri Bakanı Sovyet saldırısına karşı Türkiye'yi destekleyeceklerini açıkladı. ${ }^{43}$

NATO'nun kuruluş çalışmalarının yapıldığı günlerde, Türkiye'nin pakta dahil olma girişimlerinin kabul edilmemesinin hatalı bir karar olduğu, Türk basınında kapsamlı bir şekilde ele alınmıştır. Abidin Daver, 11 Mart 1949 tarihli Cumhuriyet Gazetesi'ndeki yazısında, müttefik devletlerin yaptıkları ittifak anlaşmasıyla Sovyet Rusya'nın Kuzey ve Batı Avrupa yönünde yayılmasının önünü kapattıklarını, ancak Sovyetlerin genişlemesi için en uygun yolun Akdeniz olduğunu ifade etmiştir. Türkiye ve Yunanistan NATO'ya alınmamasından dolayı Sovyet yayılmacılığı karşısında Akdeniz Bölgesinin savunmasız kaldığını söylemiştir. ${ }^{44}$ Yusuf Hikmet Bayur, Kudret Gazetesi'ndeki 21 Mart 1949 tarihli yazısında, Türkiye'nin, NATO dışında kalmasını değerlendirmiş ve Türk Hükümeti'nin izlemesi gereken politika hakkında görüşlerini ifade etmiştir. Bayur, yapılan anlaşmanın adı ne olursa olsun, Türkiye'nin de bu güvenlik paktına dahil olması meselesinin milli bir dava olması gerektiğini söylemiştir. ${ }^{45}$ Osman Menteşeoğlu ise Ulus Gazetesi'ndeki 26 Mart 1949 tarihli yazısında; Atlantik Paktı'nın Sovyet Rusya'ya karşı yapıldığını, ancak Akdeniz'in savunmasız bırakıldığını, bunun önleminin ne zaman ve nasıl alınacağını sormuştur. ${ }^{46}$

\footnotetext{
41،'Sadak'in Londra ve Paris Görüşmeleri”, Cumhuriyet, 21 Mart 1948, s.1.

${ }^{42}$ Yalçın vd, age, s.467-468.

${ }^{43}$ Süleyman Ekici-Abdulkadir Baharçiçek, "NATO’ya Üyelik Sürecinde Türkiye ABD İlişkileri”, Birey ve Toplum, C. VI, S. XI, 2016, s.153-156.

${ }^{44}$ Abidin Daver, “Atlantik Paktı'nın Tekâmülüne Doğru”, Cumhuriyet Gazetesi, 11 Mart 1949, s.1.

${ }^{45}$ Y. Hikmet Bayur, “Atlantik Misakı ve Diplomasimizin Başarısızlığı”, Kudret Gazetesi, 21 Mart 1949, s.1.

${ }^{46}$ Osman Menteşeoğlu, “Türk Emniyeti İçin Evham”, Ulus Gazetesi, 26 Mart 1949, s.2.
} 
NATO'nun kuruluşu ve Türkiye'nin bunun dışında bırakılması hakkında bazı devlet adamları, birçok aydın ve köşe yazarı değerlendirmede bulunmuştur. Açıklamada bulunanlardan birisi de Cumhurbaşkanı Celal Bayar'dır. Bayar, 30 Mart 1949'da Cumhuriyet Gazetesi'ne yaptığı açıklamada, yeni bir dünya savaşının çıkması halinde Türkiye'nin savaş dışı ve tarafsız kalmasının çok zor olacağını söylemiştir. Türkiye'nin NATO'ya alınmamasının büyük bir hata olduğunu söyleyen Bayar, bu hatanın en kısa sürede telafi edilmesi gerektiğini ifade etmiştir. ${ }^{47}$ Birleşmiş Milletler toplantısı için gittiği ABD'de, Türkiye'nin NATO dışında kalması hakkında Dışişleri Bakanı Necmettin Sadak bir değerlendirme yapmıştır. Yaptığı değerlendirmede Türkiye'nin güvenliğini sağlamak için NATO'ya girmek istediğini söyleyen Sadak, pakt dışında kalmanın Türk halkında hayal kırıklı̆̆ı ve hoşnutsuzluk yarattı̆̆ını ifade etmiştir. ${ }^{48}$ Dönemin önemli aydınlarından Peyami Safa, en sert tepkiyi gösteren isimlerden biri olmuştur. Safa, Ulus Gazetesi'ndeki 26 Mart 1949 tarihli yazısında ABD ve müttefiklerini hedef alarak, bizi hesaba katmayan bir güvenlik paktını bizimde hesaba katmamamız gerektiğini söylemiştir. Hatta bu durumun, Türkiye'ye dış politikada serbest hareket etme imkanı sağlayacağını iddia etmiştir. ${ }^{49}$

Hazırlıklarının tamamlanması üzerine Washington'da, 4 Nisan 1949'da İngiltere, Fransa, Lüksemburg, Belçika, Hollanda, İtalya, Danimarka, Norveç, İzlanda, Portekiz, Amerika Birleşik Devletleri ve Kanada arasında, "Kuzey Atlantik Antlaşması Örgütü (NATO: North Atlantic Treaty Organization)" kuruldu. Bir önsöz ve on dört maddeden oluşan Kuzey Atlantik Antlaşması, antlaşmayı imzalayan devletlerin yasama organları tarafından onaylandıktan sonra, 24 Ağustos 1949 'da yürürlüğe girdi. ${ }^{50}$ Böylece, İkinci Dünya Savaşı'ndan hemen sonra, meydana gelen gelişmelerin sonucunda, Batı Avrupa'dan on ve Amerika'dan iki olmak üzere toplam on iki ülkenin katılımıyla geniş kapsamlı bir savunma ittifakı oluşturdu. NATO'nun kurulmasıyla ilk defa Sovyet tehdidine karşı etkili bir set kurulmuş, aynı zamanda caydırıcı bir güç meydana getirilmiş oldu. Bu şekilde de Batı güvenlik sistemi ve Batı Blok'u ortaya çıktı. ${ }^{51}$ Avrupa'da temeli atılan ve Amerika Birleşik Devletleri'nin de desteğini alan bu geniş tabanlı savunma ittifakının hızla üye sayısı artmaya başladı. Kurulduğu ilk andan itibaren bu güvenlik şemsiyesi altına girmeye çalışan ülkelerden biri de, Sovyet Rusya ile komşu olan ve bu devletin kabul edilemez teklifleriyle zor anlar yaşayan Türkiye idi.

NATO'nun kuruluşu Türk basınında geniş yankı bulmuş, özellikle Türkiye'nin NATO dışında bırakılması şiddetle eleştirilmiştir. 31 Mart 1949 tarihli Cumhuriyet Gazetesi. İngiltere Dışişleri Bakanı Bevin'in pakt hakkında söylediklerini sütunlarına taşıdı. Gazete, Bevin'in verdiği demeçte, Kuzey Atlantik Paktı'nın gelecek birçok nesli harpten koruyacak bir pakt olduğunu söylediğini okurlarına aktarmıştır. ${ }^{52}$ Gazete 4 Nisan'daki sayısında, gün içinde imzalanacak olan anlaşmanın, yeni bir harbe mani olacak tarihi bir vesika olarak nitelemiştir. ${ }^{53}$ Aynı gazete 5 Nisan'da, Kuzey Atlantik Paktı'nı, “Artık demokrasi dünyası münferit birliklerden müteşekkil değildir" şeklinde değerlendirmiştir. 6 Nisan 1949 tarihli Cumhuriyet Gazetesi'nde NATO'nun kuruluşunun değerlendirildiği bir yazı yayınlanmıştır. Yazıda, NATO'nun kuruluşu ile Sovyet Rusya'nın karşısına demokrasi cephesinin dikildiği ifade edilmiştir. Ayrıca Pakta üye ülkelerin, ilimde, teknikte, sanayide daha zengin oldukları vurgulanmıştır. 7 Nisan tarihli sayısında ise eski dünyanın, yenidünyanın kuvvetleri ile

\footnotetext{
47،“Atlantik Paktı Dışında Kalışımız Karşısında D.P.”, Cumhuriyet, 30 Mart 1949: 1,3.

${ }^{48}$ Necmettin, Sadak, "Biz Pakt Delisi Değiliz Yalnız Şu Var Ki...", Cumhuriyet Gazetesi, 6 Nisan 1949, s.3.

${ }^{49}$ Ulus, 26 Mart 1949.

${ }^{50}$ Tekin Erer, NATO'nun Hür Ufuklarl, Baha Matbaası, İstanbul 1969, s.102.

${ }^{51}$ Soysal, age, s. 409-411; Uçarol, age, s.671.

52“"Batılı Dış Bakanları New York’a Vardılar”, Cumhuriyet, 31 Mart 1949: 1.

53،“Atlantik Paktı Bugün Washington'da İmzalanıyor”, Cumhuriyet, 4 Nisan 1949: 1.
}

\section{History Studies}


destekleneceğini ve düşmana her yerde mukabelede bulunma imkânı sağlayacağını ifade etmiştir. $^{54}$

NATO'nun kuruluşunu, Son Telgraf Gazetesi 4 Nisan tarihli sayısında "Dünyayı ilgilendiren mühim siyasi olay", "Dünya Barışının Koruyucusu Olan Pakt" başlıklı yazılarla duyurmuştur. Aynı sayıda NATO'nun, Sovyetlerin protestolarına rağmen 12 devlet tarafından Washington'da imzalanan anlaşma ile hayata geçeceği ifade edilmiştir. Gazete, 5 Nisan'daki sayısında "Atlantik Paktı Dün Törenle İmzalandı" manşeti ile NATO’nun resmen kurulduğunu okuyucularına duyurmuştur. ${ }^{55}$

\subsection{Türkiye'nin NATO'ya Girme Mücadelesi}

NATO 4 Nisan 1949 tarihinde kurulduğunda üye olarak kabul edilmemesine rağmen Türkiye, üyelik mücadelesini ısrarla sürdürdü. Türkiye’nin NATO’ya üye olma ısrarının birçok nedeni vardı. Bu nedenler arasında en önemlisi İkinci Dünya Savaşı'ndan sonra üzerinde oluşan Sovyet baskısıydı. Türkiye, NATO'ya girebilirse paktın üye ülkelere sağladığı koruma gücünden yararlanarak Sovyet tehdidine karşı topraklarının güvenliğini ve bağımsızlığını koruyabileceğini düşünüyordu. Bunun yanı sıra NATO üyeliği Türk silahlı kuvvetlerinin modernize edilmesinde kaçırılmaması gereken bir firsat olarak görülüyordu. Ayrıca, Truman Doktrini ve Marshall Planı çerçevesinde yapılan Amerikan yardımları ve ABD'nin politik desteği sayesinde Sovyet tehdidine karşı kısmen de olsa rahatlayan Türkiye'nin, dış politikadaki yalnızlıktan bir an önce kurtulma isteği etkiliydi. ${ }^{56}$

Türkiye'nin kendini tam olarak güvende hissetmek için NATO'ya girmeye çabaladığ 1 günlerde, 5 Mayıs 1949 tarihinde İngiltere, Fransa, Belçika, Hollanda, Lüksemburg, Danimarka, Norveç, İsveç, İtalya ve İrlanda arasında Avrupa Konseyi'ni kuran antlaşma imzalandı. Türkiye'nin bu antlaşmanın dışında bırakılmasına, hem Türk Hükümeti hem de Türk basını büyük tepki gösterdi. ${ }^{57}$ Türkiye'nin gösterdiği tepkiler kısa sürede sonuç verdi ve 8 Ağustos 1949'da Avrupa Konseyi'nin Strasburg'da yapılan toplantısında, Türkiye, Yunanistan ve İzlanda ile birlikte Avrupa Konseyi'ne davet edildi. 12 Aralık 1949'da TBMM'de 7382 sayılı kanunun onaylanması ile Türkiye Avrupa Konseyi'ne girdi. ${ }^{58}$

Türkiye, Avrupa Konseyi'ne girdikten sonra, batı dünyasında daha çok kabul görmek ve yalnızlığını ortadan kaldırmak için girişimlerini yoğunlaştırdı. Aralık 1949'da NATO'ya kabul edilmesi için ABD nezdinde talepte bulundu, ancak bu girişiminden de olumlu cevap alamadı. 1950 yılı Mart ayında Amerikan Akdeniz Filosuna bağlı bazı gemilerin, İstanbul ve İzmir limanlarını ziyaret etmesi, Türkiye'yi NATO'ya girme konusunda yeniden umutlandırd ${ }^{59}$ Türk Hükümeti, 11 Mayıs 1950'de NATO teşkilatına doğrudan ilk defa üyelik başvurusunda bulundu. Ancak, Türkiye'nin bu ilk başvurusu İtalya hariç olmak üzere diğer ülkeler tarafindan reddedildi. Türkiye'nin üyeliğine karşı çıkan ülkeler, gerekçe olarak Sovyetler Birliği'nin buna kesinlikle karşı çıkacağını ve bunun bir savaşa neden olacağı endişesini ifade ettiler. ${ }^{60}$

Türkiye'nin NATO üyeliğine karşı çıkan İngiltere, Türkiye'nin Ortadoğu'nun savunmasına yönelik olarak kurulacak bir kuruluşta yer almasını ve bu bölgedeki İngiliz birlikleriyle uyum

\footnotetext{
54، “Atlantik Paktı Dün Washington'da İmzalandı”, Cumhuriyet, 5 Nisan 1949: 1; 6 Nisan 1949: 1; “Atlantik Paktı'na Ait Askeri Program", Cumhuriyet, 7 Nisan 1949: 1.

55“"Dünyayı İlgilendiren Mühim Olay”, Son Telgraf, 4 Nisan 1949: 1; “Washington’da Büyük Gün”, Son Telgraf, 5 Nisan 1949: 1.

${ }^{56}$ Taşkıran, agm, s.6; Oran, age, s.543-544.

57“"Avrupa Konseyi’nin Statüsü İmzalandı”, Cumhuriyet, 6 Mayıs 1949: 1.

${ }^{58}$ Metin Toker, (1990). DP'nin Altın Ylllarl (1950-1954), Bilgi Yayınevi, İstanbul 1990, s.88.

${ }^{59}$ Yalçın vd., age, s.469.

${ }^{60}$ Sarınay, age, s.93; Uçarol, age, s.734.
} 
içinde hareket etmesi gerektiği düşüncesinde ssrar ediyordu. İngilizler, Türk ordusunu NATO yerine Türkiye ile İngiltere arasında oluşturulacak bir ittifak marifetiyle kendi Ortadoğu'daki çıkarlarının korunmasında kullanmak niyetindeydiler. Fakat Türkiye ABD'nin desteği olmadan Ortadoğu'da İngiliz-Türk işbirliğine girmeye pekte sıcak bakmıyordu. Güvenliğini teminat altına almakta kararlı olan Türkiye, sonuç olarak Ortadoğu savunma sistemine katılmayı kabul etmiş ancak, ABD'nin de dâhil olduğu bir ittifaka, yani NATO'ya üyelik ısrarını devam ettirmiştir.

NATO üyeliği mücadelesinin verildiği günlerde 14 Mayıs 1950 tarihinde yapılan genel seçimler, Türkiye'de iktidarı değiştirmiştir. İktidarı devralan Demokrat Parti, CHP Hükümeti tarafından başlatılan NATO'ya girme çabasına daha da hız verdi. ${ }^{61}$ Meclisin 22 Mayıs 1950 tarihli oturumunda Cumhurbaşkanı seçilen Celal Bayar, aynı gün toplanan bakanlar kurulunda NATO'ya girmek için çalışmaların hızlandırılması ve bütün yolların denenmesi kararı alındı. ${ }^{62}$ DP Hükümeti'nin NATO üyeliği konusunda çalışmalara hız verme kararı aldığı günlerde -1950 Haziran ayında- başlayan Kore Savaşı, üyelik mücadelesinde firsat olarak görülmüş ve değerlendirilmiştir. ${ }^{63}$

\subsection{Kore Savaşı ve Türkiye'nin NATO'ya Girişi}

25 Haziran 1950'de Kuzey Kore'nin, Güney Kore'ye saldırmasıyla Kore Savaşı fiilen başladı. Savaşın başladığı gün ABD’nin çağrısı üzerine toplanan Birleşmiş Milletler Güvenlik Konseyi, Kuzey Kore'nin silahlı güçlerinin 38. paralelin kuzeyine çekmesini istedi. ${ }^{64}$ Kuzey Kore, BM Güvenlik Konseyi'nin çekilme kararına uymayınca Birleşmiş Milletler, Güney Kore Cumhuriyetine askeri yardımda bulunulması çağrısı yaptı. Türkiye, Birleşmiş Milletlerin Kore'ye askeri birlikler gönderme çağrısına ABD'den sonra, 25 Temmuz 1950 tarihinde olumlu cevap veren ikinci ülke oldu. Başbakan Menderes, Kore'ye asker gönderilmesi kararıyla ilgili olarak yaptı̆̆ 1 açıklamada, Türkiye'nin Avrupa ülkeleri arasında kendini ispatlamak için elini çabuk tutması gerektiğini söyledi. Türk Hükümeti, Kore'deki Birleşmiş Milletler Gücü'ne 4.500 kişilik bir askeri kuvvetin gönderilmesine karar verdi. Türkiye, Kore Savaşı'nın başladığı günlerde ABD'nin ardından Kore'ye askerleri ulaşan ilk devlet oldu. ${ }^{65}$

Hükümetin Kore'ye asker gönderme kararı, Türk basınında olumlu ve olumsuz birçok haber, yorum ve değerlendirmeye konu oldu. Kore'ye 4.500 asker gönderilmesi kararını 26 Temmuz 1950 tarihli Milliyet Gazetesi beklenmeyen bir karar olarak okuyucularına duyurdu. ${ }^{66}$ Hükümetin kararı hakkında 26 Temmuz tarihli Cumhuriyet Gazetesi; BM emrinde Kore'de hizmet etmek üzere 4.500 mevcutlu Türk birliğinin Kore'ye gönderileceğini yazmıştır. ${ }^{67}$ Ali Naci Karacan, Milliyet Gazetesi'nin 27 Temmuz tarihli nüshasında yer alan yazısında; Türkiye'nin Kore'ye asker göndermesi kararının olumlu olduğunu söylemiştir. Bu kararın dünya kamuoyunda Türkiye'nin itibarını arttıracağını, sözüne güvenilir bir devlet olduğu gösteren çok isabetli bir karar odluğunu ifade etmiştir. ${ }^{68}$ Milliyet Gazetesi 2 Ağustostaki sayısında BM'nin çağrısına olumlu cevap vermeyen ülkelerin Marshall Planı'ndan aldıkları

\footnotetext{
${ }^{61}$ A. Emin Yalman, (1997). Yakın Tarihte Gördüklerim ve Geçirdiklerim (1922-1971), C.II, Pera Tur., İstanbul 1997, s.1536; Sander (1969), age, s.74-75.

${ }^{62}$ İsmet Bozdağ, Bilinmeyen Yönleriyle Celal Bayar, Türk Milletine Vasiyet, Emre Yayınları, İstanbul 2005, s.151.

${ }^{63}$ Ekinci- Baharçiçek, agm, s.157-158.

${ }^{64}$ Ayın Tarihi, S. 199, Basın Yayın ve Turizm Genel Müdürlüğ̈̈ Yay., Haziran 1950, s.117.

${ }^{65}$ Gönlübol-Ülman, age, s. 229; Uçarol, age, s.733.

66،"Hükümetin Beklenmeyen Kararı", Milliyet, 26 Temmuz 1950, s.1.

67،"Kore'de Hizmet Etmek Üzere BM Emrine Asker Veriyoruz", Cumhuriyet, 26 Temmuz 1950, s.1.

${ }^{68}$ A. Naci Karacan, "Hükümet Kararında İsabet Etmiştir”, Milliyet Gazetesi, 27 Temmuz 1950, s.5.
} 
yardımın kesileceğini iddia etmiş, bu nedenle de hükümetin Kore'ye asker göndermekle doğru karar verdiği değerlendirmesinde bulunmuştur. ${ }^{69}$

Cumhurbaşkanı Celal Bayar anılarında, Kore Savaşı'na asker gönderme kararının NATO’ya girmek için değil, BM'ye bağlı olduğumuzu göstermek için alındığını söylemiştir. Türkiye'nin NATO'ya üye olma isteği olmasa da Kore Savaşı'na asker gönderileceğini ifade etmiştir. Ancak, Kore Savaşı'na katılmamızın NATO'ya alınmamıza etki etmiş olabileceğini de kabul etmiştir. ${ }^{70}$ Başbakan Adnan Menderes ise asker gönderme kararını, Türkiye'nin bir sorumluluğunu yerine getirmesi olarak gördüğünü, davete icabet etmenin her büyük devletin görevi olduğunu ifade etmiştir. ${ }^{71}$

Hükümetin, Türkiye Büyük Millet Meclisi onayı olmadan Kore'ye asker göndermesi muhalefetin tepkisine sebep oldu. CHP Genel Sekreteri Kasım Gülek ve Millet Partisi Genel Başkanı Hikmet Bayur, asker gönderme kararının TBMM'de görüşülmeden ve diğer partilerin görüşü alınmadan, tartışılmadan yapılmasına tepki gösterdiler. Eski adalet bakanlarından Zeki Türel ise hükümetin Kore'ye asker gönderme kararının anayasaya aykırı olduğunu söyledi. ${ }^{72}$

Türk Hükümeti, Kore'ye asker gönderme kararını verdiği günlerde, 1 Ağustos 1950'de, NATO'ya üyelik için ikinci başvuruyu yaptı. İkinci başvurudan sonra Başbakan Adnan Menderes, Milliyet Gazetesine verdiği mülakatta, "önemli bir askeri güce sahip olduğu bilinen Türkiye'nin dünyanın içinde bulunduğu şartlar dahilinde NATO'ya girmesinin önemeli olduğunu, Türkiye'nin paktın güvenlik ve savunma sistemine yeni bir güç katacağını" ifade etmiştir. $^{73}$ Türkiye'nin Kore Savaşı'na katılması, Türk kamuoyunda ve yönetim kademelerinde NATO'ya kesin olarak alınacağı fikrinin oluşmasına sebep olmuştur. Dışişleri Bakanı Köprülü, Türkiye NATO'ya alınmadıkça, paktın tamamlanmış olamayacağını, Doğu Akdeniz bölgesi gibi önemli bir bölgenin ortak savunma sistemi dışında bırakılamayacağını belirtmiştir. Köprülü, Türkiye'nin NATO'ya üyelik başvurusunun reddedilmeyeceğini de söylemiştir. ${ }^{74}$

Bütün olumlu beklentilere rağmen, Türkiye'nin 1 Ağustos 1950'de yaptığı üyelik başvurusu, Eylül ayında toplanan NATO Bakanlar Konseyi tarafından reddedilmiştir. ${ }^{75}$ NATO Bakanlar Konseyi'nin Türkiye'nin üyelik başvurusunu reddetmesini Cumhurbaşkanı Celal Bayar iki sebebe dayandırıyordu. Bayar'a göre, Türkiye'nin NATO'ya alınmaması ya Türkiye'yi temsil eden devlet adamlarının çabalarının yeterli düzeyde olmaması ve bazı gelişmeleri iyi algılayamamaları ya da NATO mensuplarının Türkiye'yi tampon devlet olarak kullanmak istemeleri olabilirdi. $^{76}$

Birleşmiş Milletler Komutanlığı güçleriyle beraber savaşta yer almak üzere Türk kuvvetlerinin Kore'ye ayak basması ve muharebelerdeki üstün başarıları, Batı dünyasında Türkiye'ye karşı olumlu tepkilerin oluşmasını sağladı. Kore'de başlayan komünist saldırı Avrupa'nın güvenliğinin Avrupa'nın sınırlı coğrafyası içerisinde düşünülmesinin ne kadar yanlış olduğunu ortaya koydu. Kore Savaşı ile dünyanın daha gergin ve güvensiz bir hale gelmesi, Türkiye'nin NATO ittifakına katılmasının yararlı olacağını düşünenlerin gün geçtikçe

\footnotetext{
69،"Hükümetin Kararını Beğenmeyenler Okusun!”, Milliyet, 2 Ağustos 1950, s. 1.

${ }^{70}$ Celal Bayar, Başvekilim Adnan Menderes, (Derleyen İsmet Bozdağ), Truva Yayınları, İstanbul 2010, s.180.

${ }^{71}$ Son Telgraf, 2 Ağustos 1950, s. 1.

72،"Prof. Fuat Başgil’in İddialarına Rağmen Asker Sevki Kararı Anayasaya Aykırıdır”, Son Telgraf, 3 Ağustos 1950, s. 1.

73،“Başbakan Adnan Menderes'in Milliyet'e Çok Mühim Beyanatı”, Milliyet, 7 Ağustos 1950, s.1.

74“'Köprülü'nün Beyanatı”, Son Telgraf, 8 Ağustos 1950, s. 1.

${ }^{75}$ Gönlübol-Ülman, age, s.228.

${ }^{76}$ Özel Şahingiray, (1999). Celal Bayar'ın Söylev Ve Demeçleri: 1933-1955 Dış Politika, Türkiye İş Bankası Kültür Yayınları, Ankara 1999, s.39. 
sayısının artmasına sebep oldu. Ancak bu Türkiye'nin hemen NATO'ya kabul edilmesini mümkün kılmadı. ${ }^{77}$

Sovyetler Birliği'nin kontrolündeki Balkan devletlerinin hızla silahlanması ve Sovyetlerin, Yugoslavya üzerindeki baskıları, NATO'nun güneydoğu kanadının güçlendirilmesi görüşünü ortaya çıkardı. Bununla birlikte Kore Savaşı'nda, Türkiye'nin NATO ittifakı açısından önemini kavrayan ABD'nin Türkiye'nin üyeliği konusundaki görüşleri değişmeye başladı. Görüşleri değişen ABD, 15 Mayıs 1951'de Yunanistan ve Türkiye'nin NATO'ya alınması talebeni resmen üye ülkelere teklif etti. ${ }^{78}$ Bu teklife ilk itiraz, paktın genişlemesinin Akdeniz'de, NATO üyelerinin bir çatışmaya sürükleyebileceğini iddia eden İskandinav ve Benelüx ülkelerinden geldi. Türkiye'nin İngiltere ve Amerika Birleşik Devletleri nezdinde 1srarla yürüttüğ̈̈ pakta üyelik arayışları, ABD'nin bastırması ile neticelendi. 1951 yılı Temmuz ayında Ottawa'da düzenlenen NATO Atlantik konseyi toplantısının gündemini, Türkiye'nin pakta kabul edilmesi meselesi meşgul etti. ${ }^{79}$

18 Temmuz 1951'de İngiltere Dışişleri Bakanı Morison, Avam Kamarasında yaptığı konuşmada, Türkiye ve Yunanistan'ın NATO'ya üye olmasına destek verdiklerini ifade etti. TBMM'de 20 Temmuz 1951'de Kocaeli Milletvekili Ethem Vassaf Akan'ın, NATO'ya katılmamız hakkında İngiltere Dışişleri Bakam Mr. Morison'un Avam Kamarasında yaptı̆ğ konuşmaya dair sözlü sorusuna, Dışişleri Bakanı Fuat Köprülü sözlü olarak cevap verdi. Köprülü, "İngiltere Hükümetinin emniyet dâvamızı büyük bir anlayışla benimsemesini ve bunun gerçekleşmesi için elinden gelen gayreti sarf edeceğini beyan etmiş bulunmasını büyük bir memnuniyetle karşıladığını ifade etmiştir. Konuşmasının devamında ise haklı dâvamızın müttefikimiz İngiltere tarafından da büyük bir anlayışla benimsendiğini sizlere arz etmekle büyük bir bahtiyarlık duymaktayım..." ${ }^{" 80}$ diyerek sürdürmüştür. İngiltere'nin destek vermesi ile Türkiye'nin NATO üyeliği girişimleri ciddi bir sonuç verme noktasına geldi. NATO Bakanlar Konseyi'nin, 16-20 Eylül 1951 tarihleri arasında Ottawa'da yaptığı toplantının sonunda, özel bir oturum yapıldı. Bu özel oturumda Türkiye ve Yunanistan'ın NATO'ya üye olarak çağırılmalarına oybirliği ile karar verildi. ${ }^{81}$

Türkiye ve Yunanistan'ın NATO içindeki statülerinin belirlenmesinin ardından 15 Ekim'de Londra'daki NATO merkezinde iki ülkenin üyeliklerini içeren ek protokolün yayınlanmasıyla resmi açıklama yapıldı. Üye devletlerin açıklamayı onaylamasıyla, 22 Ekim 1951 tarihinde yürürlük süreci başladi. ${ }^{82}$ NATO Bakanlar Konseyi, Türkiye ile Yunanistan'ın NATO'ya davet edilmesi kararını 16 Şubat 1952 'de onayladı. ${ }^{83}$ Türkiye'nin NATO'ya üyelik kanunun TBMM'de görüşüldüğü 18 Temmuz günü Dış İşleri Bakanı Fuat Köprülü milletvekillerine hitaben bir konuşma yaptı. Köprülü yaptı̆̆ konuşmada; oylanacak olan üyelik kanunun, hürriyet, istiklâl, demokrasi gibi ideallere samimiyetle bağlı olan Türk Milletinin arzu ve iradesine çok uygun olduğunu söyledi. ${ }^{84}$ Dış İşleri Bakanı Fuat Köprülü'den sonra söz alan Dışişleri Komisyonu Başkanı Samsun Milletvekili, Firuz Kesim NATO üyeliği kanun tasarısının önemi üzerinde durdu. Kesim konuşmasında, NATO’ya girmekle en doğru yolun

\footnotetext{
${ }^{77}$ Feridun Cemal Erkin, "Batı Avrupa Birliği ve NATO'nun Doğuşu, Türkiye'nin NATO'ya Girişi”, Türkiye ve Nato, Türk Atlantik Antlaşması Derneği Yayınları, Ajans-Türk Matbaacılık Sanayi, Ankara Tarih Belirsiz, s.17.

${ }^{78}$ Cünet Akalın, Soğuk Savaş, ABD ve Türkiye, C. I, Kaynak Yayınları, İstanbul 2003, s. 253; Gönlübol-Ülman, age, s.229.

${ }^{79}$ Ekinci- Baharçiçek, agm, s.160-161.

${ }^{80}$ T.B.M.M. Tutanak Dergisi, Dönem 9, Cilt 9, 20.07. 1951, s. 231-232.

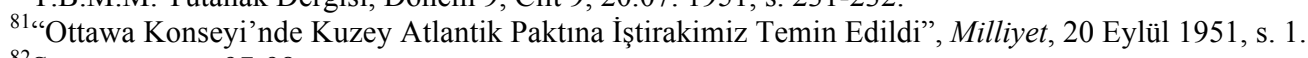

${ }^{82}$ Sarınay, age, s.97-98.

${ }^{83}$ Ersin Embel, (2004). “Türkiye'nin NATO Serüveni”, Popüler Tarih Dergisi, S. 46, İstanbul Haziran 2004, s.52.

${ }^{84}$ TBMM Tutanak Dergisi, Dönem 9, C. 18, 18.11.1952, s.315.
} 
seçildiğinden hiç şüphe olmadığını ifade ettikten sonra, medeniyet ve ilerleme yolunda örnekler vermiş on dört güzide milletin, hür dünyayı, insan haklarını ve medeniyetin müşterek varlığını, her türlü tecavüze karşı müdafaa noktasında birleştiğine dikkat çekti. ${ }^{85}$

TBMM'de 18 Şubat 1952 tarihinde Türkiye'nin NATO'ya girmesine ilişkin kanunu, oylaması sırasında TBMM'de 487 milletvekili bulunuyordu. Oylamaya katılan milletvekili sayıs1 410 olmuş, bunlardan 409'u kabul, bir vekil çekimser oy verirken 74 milletvekili oylamaya katılmamıştır. ${ }^{86}$ TBMM'de kabul edilen 8038 numaralı bu kanun, 19 Şubat 1952 tarihli Resmi Gazete de yayınlanarak yürürlüğe girdi. NATO'nun Portekiz'in Başkenti Lizbon'da 20-25 Şubat 1952 tarihleri arasında yaptığı toplantısına, Türkiye ilk defa tam üye sifatıyla katıld1. ${ }^{87}$

Türkiye'nin NATO'ya üye olması Türk kamuoyunda ve basınında kapsamlı olarak yer aldı. Basında, TBMM'de NATO'ya katılma kararının oy birliğiyle alınması ve eşit şartlarda NATO'ya üye olunması önemli bir başarı olarak değerlendirildi. ${ }^{88}$ Nadir Nadi, 19 Şubat 1952 tarihli Cumhuriyet Gazetesi'ndeki yazısında, NATO üyeliğinin milli bir zafer olduğunu ve kamuoyunda memnuniyetle karşılandığına vurgu yaptı. Ayrıca, üyeliğin bazı sorumluluklar getirdiğine de dikkat çekerek, milli varlığımız, bağımsızlığımız ve özgür dünyaya karşı üstlenilen sorumluluğun ağırlığının farkında olması gerektiği hususunda uyarlarda da bulundu. ${ }^{89}$ Falih Rıfk1 Atay, Türkiye'nin NATO üyeliği ile sadece güvenliğini garanti altına almadığını, bazı görev ve sorumluluklarında altına girdiğini ifade ettikten sonra, Türkiye'nin bundan böyle Üçüncü Dünya Savaşı'nın dışında kalamayacağı ifadelerini kullandı. ${ }^{90}$

Dışişleri Bakanı Fuat Köprülü, Türkiye'nin NATO’ya girişi hakkında görüşlerini ifade ederken, NATO'nun demokratik rejimleri, medeniyetleri ve barışı korumak için kurulduğunu söyledi. Köprülü, Türk halkının tarihi boyunca barışa ve demokratik prensiplere saygı duyduğunu, bundan dolayı Türkiye'nin NATO'ya üye olmasından mutluluk duyduğunu ifade etti. ${ }^{91}$ Türkiye'nin NATO'ya üye olması, kamuoyunun çoğunluğu tarafından olumlu karılanmış ve zafer olarak nitelendirilmiştir. Türkiye'nin demokrasi cephesinde yer alması ve üyelik kararının oy birliği ile alınması memnuniyetle karşılanmıştır. Türkiye'nin NATO'ya eşit haklarla kabul edilmesi ve ABD ile aynı ittifakta yer alması sevinç yaratmıştır.

\footnotetext{
${ }^{85}$ TBMM Tutanak Dergisi, Dönem 9, C. 18, 18.11.1952, s.316-317.

${ }^{86}$ TBMM Tutanak Dergisi, Dönem 9, C. 18, 18.11.1952, s. 343-346.

${ }^{87}$ Resmi Gazete, 19 Şubat 1952, s. 1.

88“"Millet Meclisi’nin Dünkü Tarihi Kararı”, Cumhuriyet, 19 Şubat 1952; "Meclis Pakta İştirakimizi Tasvip Etti”, Hürriyet, 19 Şubat 1952; "Büyük Millet Meclisi’nin Dünkü Tarihi Celsesi”, Milliyet, 19 Şubat 1952.

${ }^{89}$ Nadir Nadi, "Kararın Manası", Cumhuriyet Gazetesi, 19 Şubat 1952, s.1.

${ }^{90}$ F. Rifk1 Atay, "Atlantik Paktı", Ulus Gazetesi, 22 Şubat 1952, s.2.

${ }^{91}$ Mehmet Saray, Sovyet Tehdidi karşısında Türkiye'nin NATO'ya Girişi, III. Cumhurbaşkanı Celal Bayar'ın Hatıraları ve Belgeler, Atatürk Araştırma Merkezi, Ankara 2000, s.115.
} 


\section{Sonuç}

İkinci Dünya Savaşı'nın dışında kalmayı başaran Türkiye, savaş sonunda yayılmacı bir siyaset izleyen Sovyet Rusya'nın toprak talebi ve Türk Boğazlarında üs talebini ihtiva eden tehditleri ile karşılaştı. Türkiye, Sovyet tehditleri karşısında bağımsızlığını ve toprak bütünlüğünü muhafaza edebilmek için Avrupalı devletlerle ittifaklar yapma arayıșına girdi. Uzun süren çabaları sonunda Türkiye, önce Truman Doktrini ve Marshall Planı çerçevesinde yapılan yardımlardan yararlandı. Ancak, Türkiye'nin NATO dışında bırakılması Türk basınında şiddetle eleştirildi. 5 Mayıs 1949'da Avrupa Konseyi'ni kuran antlaşmaya dahil edilmemesine hem Türk Hükümeti hem de Türk basını büyük tepki gösterdi. Tepkileri sonuç veren Türkiye, 8 Ağustos 1949'da Avrupa Konseyi'ne davet edildi ve 12 Aralık 1949'da Avrupa Konseyi üyesi oldu. Türk Hükümeti, 11 Mayıs 1950'de ilk defa doğrudan NATO'ya üyelik başvurusunda bulundu. Ancak, Türkiye'nin bu ilk başvurusu İtalya hariç diğer ülkeler tarafından reddedildi. 1950 Haziran ayında- başlayan Kore Savaşı, üyelik mücadelesinde fırsat olarak görüldü. Türk Hükümeti, Kore'deki Birleşmiş Milletler Gücü'ne 4.500 kişilik bir askeri kuvvetin gönderilmesine karar verdi. Hükümetin Kore'ye asker gönderme kararı, Türk basınında olumlu ve olumsuz birçok haber, yorum ve değerlendirmeye konu oldu. Türkiye'nin 1 Ağustos 1950'de, NATO'ya üyelik için yaptığı ikinci başvuru da Eylül ayında toplanan NATO Bakanlar Konseyi tarafından reddedildi.

Türk kuvvetlerinin Kore muharebelerindeki başarıları, Batı dünyasında Türkiye'ye karşı bakış açısının değişmesini sağladı. Türkiye'nin NATO ittifakı açısından önemini kavrayan ABD'nin Türkiye'nin üyeliği konusundaki görüşleri değişti. ABD, 15 Mayıs 1951'de Yunanistan ve Türkiye'nin NATO'ya alınması talebeni üye ülkelere teklif etti. Türkiye'nin İngiltere ve Amerika Birleşik Devletleri nezdinde 1srarla yürüttüğü pakta üyelik arayışları, ABD'nin bastırması ile neticelendi. NATO Bakanlar Konseyi’nin, 16-20 Eylül 1951 tarihleri arasında Ottawa'da yaptığı toplantının sonunda yapılan özel bir oturumda, Türkiye'nin NATO'ya üye olarak çağırılmasına oybirliği ile karar verildi. NATO Bakanlar Konseyi, Türkiye'nin NATO'ya davet edilmesi kararını 16 Şubat 1952'de onayladı. Türkiye'nin NATO'ya girmesine ilişkin kanunu 18 Şubat 1952 tarihinde, TBMM'de onaylandı ve 19 Şubat 1952 tarihli Resmi Gazete de yayınlanarak yürürlüğe girdi. Türkiye uzun mücadelelerden sonra nihayet resmen NATO üyesi oldu.

NATO üyesi olduktan sonra Türkiye ile ABD arasında ikili ilişkiler gelişti ve Amerika'nın Ortadoğu ile olan ilişkisinde Türkiye en yakın müttefiki oldu. Ancak, NATO'ya girişle birlikte Türk dış politikasında çok köklü değişimler meydana geldi. NATO içerisinde Amerika Birleşik Devletleri'nin tartışmasız liderliği, Amerikan askeri kuvvetlerinin Türk topraklarında yerleşmesi ve bunu izleyen çok yönlü ilişkiler, Türk yöneticilerinin NATO ile ABD’yi özdeş tutmalarına sebep oldu. Üye olduktan sonra, NATO Türkiye için güvenliğini sağlayan bir ittifaktan çok, Türkiye'nin ABD ile askeri, ekonomik ve toplumsal ilişkilerine, yani Amerikan varlığına biçim veren bir çerçeve niteliği kazand. Bu nedenle Türkiye'nin NATO'ya girişi, bir devletin güvenliği açısından başka bir devletle ittifaka girmesinin ötesinde bir anlam taşımaktadır. Türkiye'nin NATO'ya girişi, gerek Türk dış politikasında gerekse iç politika da önemli sonuçlar doğurdu. 


\section{Kaynakça}

\section{a. Kitap ve Makaleler}

AKALIN, Cüneyt, Soğuk Savaş, ABD ve Türkiye, C. I, Kaynak Yayınları, İstanbul 2003.

AKŞİN, Aptülahat, Türkiye'nin 1945'den Sonraki Dış Politika Gelişmeleri, Ortadoğu Meseleleri, İsmail Akgün Matbaacılık ve Kitapç1lık Müesseseleri, İstanbul 1959.

ARMAOĞLU, Fahir, 20. Yüzyıl Siyasi Tarihi (1914-1980), C. I, İş Banaksı Yayınları, Ankara 1991.

ARSIN, Ali, “Soğuk Savaş'ın Kaynakları ve NATO'nun Kuruluşuna Yol Açan Gelişmeler”, NATO Savunma ve Ĕ̈itim Yönleri Sempozyumu, Ankara Üniversitesi Eğitim Bilimleri Fakültesi Yayınları, No:133, Ankara 1984.

ATAK, Sadık, Harp Sonrasında Dünya, (1945-1966), Ankara Basım ve Ciltevi, Ankara 1966.

ATAÖV, Türkkaya, Amerika-Nato ve Türkiye, Aydınlık Yayınevi, Ankara 1969.

ATAY, F. R1fk1, “Atlantik Paktı”, Ulus Gazetesi, 22 Şubat 1952.

BAYAR, Celal, Başvekilim Adnan Menderes, (Derleyen: İsmet Bozdağ), Truva Yayınları, İstanbul 2010.

BAYUR, Y. Hikmet, “Atlantik Misakı ve Diplomasimizin Başarısızlı̆̆ı”, Kudret Gazetesi, 21 Mart 1949.

BOWEN, Wayne, Türkiye ve İkinci Dünya Savaşı: Taraflı Fakat Savaşmayan Ülke, (Çeviren: Mehmet Emin Baysal), Türkler Ansiklopedisi, C. XVI, (Editörler: Kemal Çiçek ve Diğerleri), Yeni Türkiye Yayınları, Ankara 2002, s. 803-812.

BOZDAĞ, İsmet, Bilinmeyen Yönleriyle Celal Bayar, Türk Milletine Vasiyet, Emre Yayınları, İstanbul 2005.

ÇOMAK, Hasret, “İkinci Dünya Harbi ve Türkiye, Harbin Sonrasında Türkiye-ABD İlişkileri, ABD’nin Türkiye'ye Yardım Politikası (Truman Doktrini ve Marshall Planı)", Altıncı Askeri Tarih Semineri Bildirileri I, Genelkurmay Basımevi, Ankara 1998, s.459-490.

DAVER, Abidin, “Atlantik Paktı'nın Tekâmülüne Doğru”, Cumhuriyet Gazetesi, 11 Mart 1949.

DERINGGíl, Selim, Denge Oyunu; İkinci Dünya Savaşı'nda Türkiye’nin Dış Politikası, Tarih Vakfi Yurt Yayınları, İstanbul 2003.

DURMUŞ, Remzi, Geçmişten Günümüze Türk Amerikan Iliş̧kileri, http://www.tasam.org/ gecmisten_gunumuze_turk_amerikan_iliskileri, 1 Ocak 2019.

EKİCI, Süleyman-Abdulkadir Baharçiçek, "NATO'ya Üyelik Sürecinde Türkiye ABD İlişkileri”, Birey ve Toplum, C. VI, S. XI, 2016, s.149-166.

EMBEL, Ersin, “Türkiye'nin NATO Serüveni”, Popüler Tarih Dergisi, S. 46, İstanbul Haziran 2004, s.52-53.

ERER, Tekin, NATO'nun Hür Ufukları, Baha Matbaası, İstanbul 1969. 
ERKINN, Feridun Cemal, "Batı Avrupa Birliği ve NATO'nun Doğuşu, Türkiye'nin NATO’ya Girişi”, Türkiye ve Nato, Türk Atlantik Antlaşması Derneği Yayınları, Ajans-Türk Matbaacılık Sanayi, Ankara (Tarih Belirsiz), s.5-34.

ERKİN, Feridun Cemal, Dışişlerinde 34 Yll, Anılar-Yorumlar, C. I, TTK Yayınları, Ankara 1987.

ESENBEL, Melih, Türkiye'nin Batı ile İttifaka Yönelişi, İsis Yayımcılık, İstanbul 2000.

ESMER, A. Şükrü- Oral Sander, vd., Olaylarla Türk Dış Politikası, Alkım Yayınevi, Ankara 1989.

GÖNLÜBOL, Mehmet-A. Haluk Ülman, Olaylarla Türk Dış Politikası, (1945-1965 Dönemi), Siyasal Kitabevi Yayınları, Ankara 1996.

JAESCHKE, Gothard, “I. Ve II. Dünya Savaşları'nda Türkiye'nin Dış Politikası”, Türkler Ansiklopedisi, C. XVI, (Editörler: Kemal Çiçek ve Diğerleri), C. XVI, Yeni Türkiye Yayınları, Ankara 2002, s. 798-802.

KARACAN, Ali Naci "Hükümet Kararında İsabet Etmiştir", Milliyet Gazetesi, 27 Temmuz 1950.

KENNEDY, Paul, Büyük Güçlerin Yükselişi ve Çöküşleri, (16. Yüzyıldan Günümüze Ekonomik Değişim ve Askeri Çatışmalar), (Çeviren: Birtane Karanakçı), İş Bankası Yayınları, İstanbul 2002.

MENTEŞEOĞLU, Osman, “Türk Emniyeti İçin Evham”, Ulus Gazetesi, 26 Mart 1949.

MERAM, Ali Kemal, Türk-Rus İlişkileri Tarihi, Kitaş Yayınları, İstanbul 1969.

NADİ, Nadir, "Kararın Manası”, Cumhuriyet Gazetesi, 19 Şubat 1952.

NEVINS, Allan-Henry Steele Commager, Amerika Birleşik Devletleri Tarihi, (Çeviren Halil İnalc1k), Varlık yayınevi, İstanbul 1961.

ORAN, Baskın, Türk Dış Politikası,1919-1980, C.I, İletişim Yayınları, İstanbul 2002.

ÖKSÜZ, Hikmet, "Türkiye Cumhuriyeti Devleti'nin Balkan Politikası”, Türk Dış Politikası - Cumhuriyet Dönemi, C. II, Gökkubbe Yayınları, İstanbul 2008.

SADAK, Necmettin, "Biz Pakt Delisi Değiliz Yalnız Şu Var Ki...”, Cumhuriyet Gazetesi, 6 Nisan 1949.

SANDER, Oral, Balkan Gelişmeleri ve Türkiye (1945-1965), Sevinç Matbaası, Ankara 1969.

SANDER, Oral, Türk-Amerikan İlişkileri 1947-1964, Ankara Üniversitesi Siyasal Bilgiler Fakültesi Yayınları, Ankara 1979.

SANDER, Oral, Türkiye'nin Dış Politikası, İmge Kitabevi Yayınları, İstanbul 2006.

SARAY, Mehmet, Sovyet Tehdidi karşısında Türkiye'nin NATO’ya Girişi, III. Cumhurbaşkanı Celal Bayar'in Hatıraları ve Belgeler, Atatürk Araştırma Merkezi, Ankara 2000.

SARINAY, Yusuf, Türkiye'nin Bati İttifakl'na Yönelişi ve NATO'ya Girişi (1939-1952), Kültür ve Turizm Bakanlığı Yayınları, Ankara 1988.

SOYSAL, İsmail, Türkiye’nin Uluslararast Siyasal Bağıtları (1945-1990), C.II, TTK. Yayınları, Ankara 1991.

\section{History Studies}


ŞAHİNGİRAY, Özel, Celal Bayar'ın Söylev Ve Demeçleri: 1933-1955 Dış Politika, Türkiye İş Bankası Kültür Yayınları, Ankara 1999.

TAŞKIRAN, Cemalettin, “Türkiye Niçin NATO’ya Girdi”, Askeri Tarih Bülteni, C.XXV, S. 49, Genelkurmay Basımevi, Ankara 2000.

TOKER, Metin, DP'nin Altın Yılları (1950-1954), Bilgi Yayınevi, İstanbul 1990.

UÇAROL, Rifat, Siyasi Tarih (1789-1999), Filiz Kitabevi, İstanbul 2000.

ULUKSAR, Gündüz, (1999). “İkinci Dünya Savaşı Öncesi ve Savaşın Devamında TürkRus İlişkileri”, Altıncı Askeri Tarih Semineri Bildirileri II, Genelkurmay Basımevi, Ankara 1999, s.389-408.

ÜLMAN, A. Haluk, Türk-Amerikan Diplomatik Münasebetleri, 1939-1947, Sevinç Matbaası, Ankara 1961.

YALÇIN, Durmuş, vd., Türkiye Cumhuriyeti Tarihi II, Atatürk Araştırma Merkezi Yayınları, Ankara 2002.

YALÇIN, H. Cahit, “Üçüncü Dünya Harbi Tehlikesi Karşısında Türkiye”, Tanin Gazetesi, 27 Haziran 1945.

YALMAN, A. Emin, Yakın Tarihte Gördüklerim ve Geçirdiklerim (1922-1971), C.II, Pera Turizm, İstanbul 1997.

\section{b. Süreli Yayınlar}

“Atlantik Paktı Bugün Washington'da İmzalanıyor”, Cumhuriyet, 4 Nisan 1949.

“Atlantik Paktı Dışında Kalışımız Karşısında D.P.”, Cumhuriyet, 30 Mart 1949.

“Atlantik Paktı Dün Washington'da İmzalandı", Cumhuriyet, 5 Nisan 1949.

“Atlantik Paktı'na Aid Askeri Program”, Cumhuriyet, 7 Nisan 1949.

“Avrupa Konseyi’nin Statüsü İmzalandı”, Cumhuriyet, 6 Mayıs 1949.

“Başbakan Adnan Menderes'in Milliyet'e Çok Mühim Beyanatı”, Milliyet, 7 Ağustos 1950.

“Batılı Dış Bakanları New York'a Vardılar”, Cumhuriyet, 31 Mart 1949.

“Büyük Millet Meclisi’nin Dünkü Tarihi Celsesi”, Milliyet, 19 Şubat 1952.

“Dünyayı İlgilendiren Mühim Olay”, Son Telgraf, 4 Nisan 1949.

“Hükümetin Beklenmeyen Kararı”, Milliyet, 26 Temmuz 1950.

“Hükümetin Kararını Beğenmeyenler Okusun!”, Milliyet, 2 Ağustos 1950.

“Kore'de Hizmet Etmek Üzere BM Emrine Asker Veriyoruz”, Cumhuriyet, 26 Temmuz 1950 .

“Köprülü’nün Beyanatı”, Son Telgraf, 8 Ağustos 1950.

“Meclis Pakta İştirakimizi Tasvip Etti”, Hürriyet, 19 Şubat 1952.

“Millet Meclisi’nin Dünkü Tarihi Kararı”, Cumhuriyet, 19 Şubat 1952.

“Milli Şefin Tarihi Nutku”, Cumhuriyet, 2 Kasım 1945.

\section{History Studies}


“Ottawa Konseyi’nde Kuzey Atlantik Paktına İştirakimiz Temin Edildi”, Milliyet, 20 Eylül 1951.

"Prof Fuat Başgil'in İddialarına Rağmen Asker Sevki Kararı Anayasaya Aykırıdır”, Son Telgraf, 3 Ağustos 1950.

“Sadak’’n Londra ve Paris Görüşmeleri”, Cumhuriyet, 21 Mart 1948.

“San Francisco’ya Dün Resmen Davet Edildik”, Cumhuriyet, 7 Mart 1945.

“Washington’da Büyük Gün”, Son Telgraf, 5 Nisan 1949.

Ayın Tarihi, S. 199, Basın Yayın ve Turizm Genel, Müdürlüğü Yayınları, Haziran 1950.

Cumhuriyet, 6 Nisan 1949.

Cumhuriyet, 24 Şubat 1945.

Resmi Gazete, 19 Şubat 1952.

Son Telgraf, 2 Ağustos 1950.

T.B.M.M. Tutanak Dergisi, Dönem 9, C. 9, 20.07. 1951.

TBMM Tutanak Dergisi, Dönem 9, C. 18, 18.11.1952.

Ulus, 26 Mart 1949. 